\title{
Serotyping and categorisation of Escherichia coli strains isolated between 1958 and 1992 from diarrhoeal diseases in Asia
}

\author{
K. TAMURA, R. SAKAZAKI*, M. MURASE† and Y. KOSAKO +
}

Department of Bacteriology, National Institute of Health, Toyama, Shinjuku-ku, Tokyo 162, †Department of Bacteriology, Kobe City Institute of Public Health. Nakamachi, Minatojima, Chuou-ku, Kobe, Hyogo 650 and ¥Japanese Collection of Microoganisms, Riken, Wako, Saitama 351-01, Japan

\begin{abstract}
A total of 3065 strains of Escherichia coli isolated between 1958 and 1992 from patients with diarrhoea in different countries were examined for virulence factors by hybridisation with biotinylated DNA probes for genes that coded for production of heat-labile and heat-stable enterotoxins, enteroinvasiveness, production of verotoxins and attaching-and-effacing factor and were serotyped. Of the 3065 strains, 1998 were placed into one of four pathogenic categories by their virulence factors: 1057 enterotoxigenic $E$. coli (ETEC) comprising 30 O-groups, 73 serovars and 137 untypable strains; 132 enteroinvasive $E$. coli (EIEC) comprising 11 O-groups and 13 serovars; 64 verotoxinproducing $E$. coli (VTEC) comprising 11 O-groups, 17 serovars and 13 untypable strains; and 745 enteropathogenic $E$. coli (EPEC) comprising 34 O-groups, 92 serovars and 91 untypable strains. The remaining 1067 strains did not hybridise with any of the DNA probes used. About half the number of $O$-groups recognised were not restricted to a single pathogenic category, although the combinations of $O$ - and $H$-antigens were different in each category.
\end{abstract}

\section{Introduction}

Following recognition as a human diarrhoeagenic pathogen and the establishment of a serotyping system, Escherichia coli serovars associated with diarrhoeal diseases have gained increasing interest in all parts of the world. There are numerous reports of the serotypes of $E$. coli strains isolated from patients with diarrhoea. Initially the classification of enteropathogenic $E$. coli isolates relied essentially on historical and epidemiological findings, because the mechanism by which $E$. coli produced diarrhoeal diseases was not known. Now four principal categories of pathogenic $E$. coli are recognised in diarrhoeal diseases according to the virulence factors implicated: enterotoxigenic $E$. coli (ETEC), enteroinvasive E. coli (EIEC), verotoxin (Shiga-like toxin)-producing or enterohaemorrhagic $E$. coli (VETC or EHEC) and enteropathogenic E. coli (EPEC).

Received 2 Sept. 1995; revised version accepted 15 March 1996.

Corresponding author: Dr K. Tamura.

*Present address: c/o Asuka Jun-Yaku, 2-4 Kanda-Sudacho, Chiyoda-ku, Tokyo 101, Japan.
Since 1958, serotyping of E. coli isolates from patients with diarrhoea in Japan has been carried out routinely at the Enterobacteriology Laboratory of the National Institute of Health, Tokyo. The results obtained up to 1974 were reported by Sakazaki et al. [1,2]. From 1980, in addition to serotyping, various tests to demonstrate the virulence potential of each of the four categories of $E$. coli have been introduced into the laboratory routine as they became available. In this report, the results of serotyping and of assays of virulence factors on 3065 strains of $E$. coli collected up to 1992 are described.

\section{Materials and methods}

\section{E. coli strains}

The 3065 isolates of $E$. coli examined were received originally for serotyping at the National Institute of Health, Tokyo between 1958 and 1992. All were submitted as isolates from patients with diarrhoea in Japan, Southeast Asia, India and the Middle East. However, epidemiological information such as patient age and scale of infection was not available in most cases. After an initial examination for purity, and 
biochemical characterisation, all the strains were stored in rubber-stoppered bottles on semi-solid medium containing Bacto-Casitone (Difco) 1\%, yeast extract $0.3 \%, \mathrm{NaCl} 0.5 \%$ and agar $0.3 \%$ and were kept at room temperature in the dark.

\section{Serotyping}

All strains were serotyped with 176 O-antisera representing 173 recognised $\mathrm{O}$-antigens of $E$. coli, three O-antigens from Ewing (OX2, OX4 and OX13) to which antigen numbers have not been assigned and 57 E. coli $\mathrm{H}$-antisera. The agglutination methods used were based on those described by Ewing [3].

\section{Virulence factor assay}

Although 650 strains in this collection examined before 1985 were tested for enterotoxin production with Y1 adrenal cells and infant mice and for invasiveness with HEp-2 cells, the remaining 2415 strains were assayed for genes coding for the production of both heat-labile and heat-stable enterotoxins (LT and ST), enteroinvasiveness, production of verotoxins (VT1 and VT2), and $E$. coli attachment-and-effacing factor (EAE) with biotinylated DNA probes as described previously [46]. The following specific gene probes were used: LT, a 850-bp HincII fragment from plasmid pEWD 299 [7]; ST1a, a 157-bp EcoRI-Bam HI fragment from pDAS 101 [8]; ST1b, a 215-bp Bam HI-Pst I fragment from pDAS 100 [8]; EIEC, a 17-kbp EcoRI fragment from pRM 17 [9]; VT1, a 1142-bp Bam HI fragment from pJN 37-19 [10]; VT2, a 842-bp Pst I-SmaI fragment from pNN 110-8 [10]; and EAE, a 1-kbp Sal I-Kpn I fragment from pCVD 434 [5]. The DNA probe fragments were labelled with biotin-7-dATP (BRL).

\section{Pathogenic categorisation of strains}

$E$. coli strains with demonstrable virulence factors were categorised according to the following criteria: ETEC for strains that hybridised with the LT or ST probe or both; EIEC for strains that hybridised with the probe for EIEC; VTEC for strains that hybridised with the VT1 or VT2 probe or both; and EPEC for strains, regardless of their serovar, that hybridised with the EAE probe but not the VT probes.

More recently, two additional categories of pathogenic $E$. coli, enteroaggregative $E$. coli (EAggEC) and diffuse adherent $E$. coli (DAEC), have been identified. However, these two categories were not considered in this study, as their significance as causes of diarrhoeal disease is still controversial.

\section{Results}

Of 3065 strains of $E$. coli examined, virulence factors were demonstrated in 1998. These were divided into the following groups: 1057 ETEC, 132 EIEC, 64 VTEC and 745 EPEC. The serovars of 1757 of these 1998 strains were identified, but those of the remaining 241 strains could not be determined either because they were in the R-form or because they did not react with any of the antisera. The serovars of the strains in each pathogenic category are shown in Tables 1-4.

\section{ETEC (Table 1)}

Most of the ETEC strains were from outside Japan. The 1057 ETEC strains consisted of 920 serotypable and 137 untypable strains. The 920 typable strains comprised $30 \mathrm{O}$-groups and 73 serovars. O-groups most frequently recognised included $\mathrm{O} 6, \mathrm{O} 8, \mathrm{O} 15, \mathrm{O} 25$, O27, O63, O73, O78, O114, O119, O126, O127, O128, O146, O148, O153, O159, O161, O167, O168 and O169. Of these O-groups, O6 which included two serovars, O6:K15:H16 and O6:K15:NM, was the predominant O-serogroup representing 292 (31.7\%) of the 920 ETEC typable strains. Significant differences in the geographic distribution of strains with O-groups recognised frequently were not observed.

\section{EIEC (Table 2)}

The 132 strains that hybridised with the probe for EIEC represented 11 O-groups. Most of EIEC strains were non-motile; motile strains were found in only nine instances. Of the 11 O-groups, O28, O124, O136 and O144 were predominant. None of these 11 O-groups occurred among the other pathogenic categories, ETEC, VTEC and EPEC. Forty-four of the strains were late fermenters of lactose and did not produce gas from glucose.

\section{VTEC (Table 3)}

The serovars of 51 of the 64 strains that hybridised with VT1 or VT2 probes or both were determined. The 51 strains comprised $11 \mathrm{O}$-groups and 17 serovars. Of the $11 \mathrm{O}$-groups, $\mathrm{O} 157$ was the most frequent followed by O103, O111, and O26. Many of the VTEC strains, but not all, also hybridised with the EAE probe.

\section{EPEC (Table 4)}

EPEC strains are usually characterised by the production of attaching-and-effacing factor (EAE), causing lesions in the enterocyte brush border membrane, as well as by the production of fimbrial adherence factor (EAF). However, the EAE factor is also produced by VTEC strains and the adherence factor EAF occurs only in some EPEC serovars (class 1 EPEC). Therefore, in the present study the EPEC category was defined as strains that hybridised with the EAE probe but not with any of LT, ST and VT probes.

Of the 745 strains included in the EPEC category, 654 were identified to serovar level. The 654 strains 
Table 1. Serovars of 1057 strains of enterotoxigenic E. coli

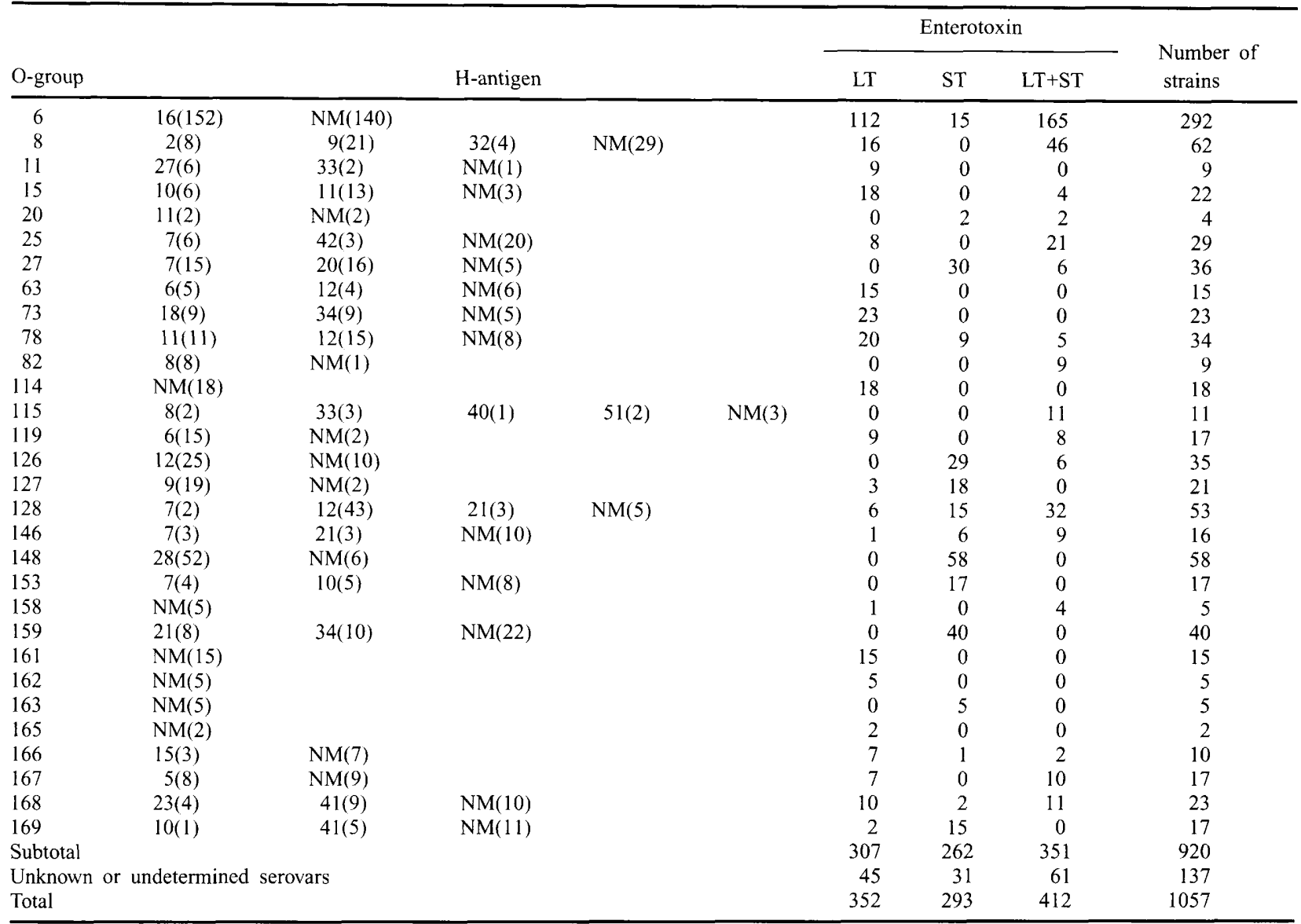

Figures in parentheses indicate the number of strains.

NM, non-motile strain.

Table 2. Serovars of 132 strains of enteroinvasive $E$. coli

\begin{tabular}{|c|c|c|c|}
\hline O-group & \multicolumn{2}{|c|}{$\mathrm{H}$-antigen } & $\begin{array}{l}\text { Number of } \\
\text { strains }\end{array}$ \\
\hline 7 & $\mathrm{NM}(3)$ & & 3 \\
\hline 28 & $\mathrm{NM}(26)$ & & 26 \\
\hline 29 & $\mathrm{NM}(8)$ & & 8 \\
\hline 124 & $30(2)$ & NM(15) & 17 \\
\hline 136 & $\mathrm{NM}(29)$ & & 29 \\
\hline 143 & $\mathrm{NM}(8)$ & & 8 \\
\hline 144 & $25(7)$ & $\mathrm{NM}(10)$ & 17 \\
\hline 152 & NM(6) & & 6 \\
\hline 164 & $\mathrm{NM}(6)$ & & 6 \\
\hline 171 & $\mathrm{NM}(5)$ & & 5 \\
\hline 173 & $\mathrm{NM}(7)$ & & 7 \\
\hline Total & & & 132 \\
\hline
\end{tabular}

Figures in parentheses indicate the number of strains.

NM, non-motile strain.

comprised $34 \mathrm{O}$-groups and 92 serovars. The O-groups found most frequently were: $\mathrm{O} 18, \mathrm{O} 26, \mathrm{O} 44, \mathrm{O} 55$, O86, O103, O111, 0114, O119, O125, O126, O127, O-128, O142, O153, O159, O160, O165, O166 and O167. Five strains of serogroup O157, a well-known VTEC O-group, gave positive reactions in tests for sorbitol fermentation and $\beta$-glucuronidase activity, unlike the VTEC O157 strains.

\section{Discussion}

In the study, 1067 of 3065 E. coli strains did not hybridise with any of the virulence factor gene probes used, although some of the strains belonged to the same O-groups or serovars as those of the ETEC, EPEC or VTEC category. However, the E. coli strains studied were collected over a period of 30 years. It is considered likely, therefore, that some had lost genes for virulence factors during storage and subculture.

The allocation of strains to the EPEC and VTEC categories in this study must also be considered. As well as EAE and verotoxin production, adherence factors are important for virulence potential in these E. coli strains. However, the adherence factor in EPEC and VTEC is not limited to a single category. Indeed, EAF, which is an adherence factor in EPEC strains, is present only in certain EPEC O-groups, termed class 1 [11]. It is interesting that enteroaggregative strains of E. coli (EAggEC) have been implicated epidemiologically as one of the aetiological agents of diarrhoea [12-14]. Even in EPEC serogroups, it has been suggested that EAggEC strains are probably more important than those which are EAF-positive [15]. On the other hand, it has also been proposed that some $E$. coli strains showing 'diffuse adherence' (DAEC) also 
Table 3. Serovars of 64 strains of verotoxin-producing $E$. coli

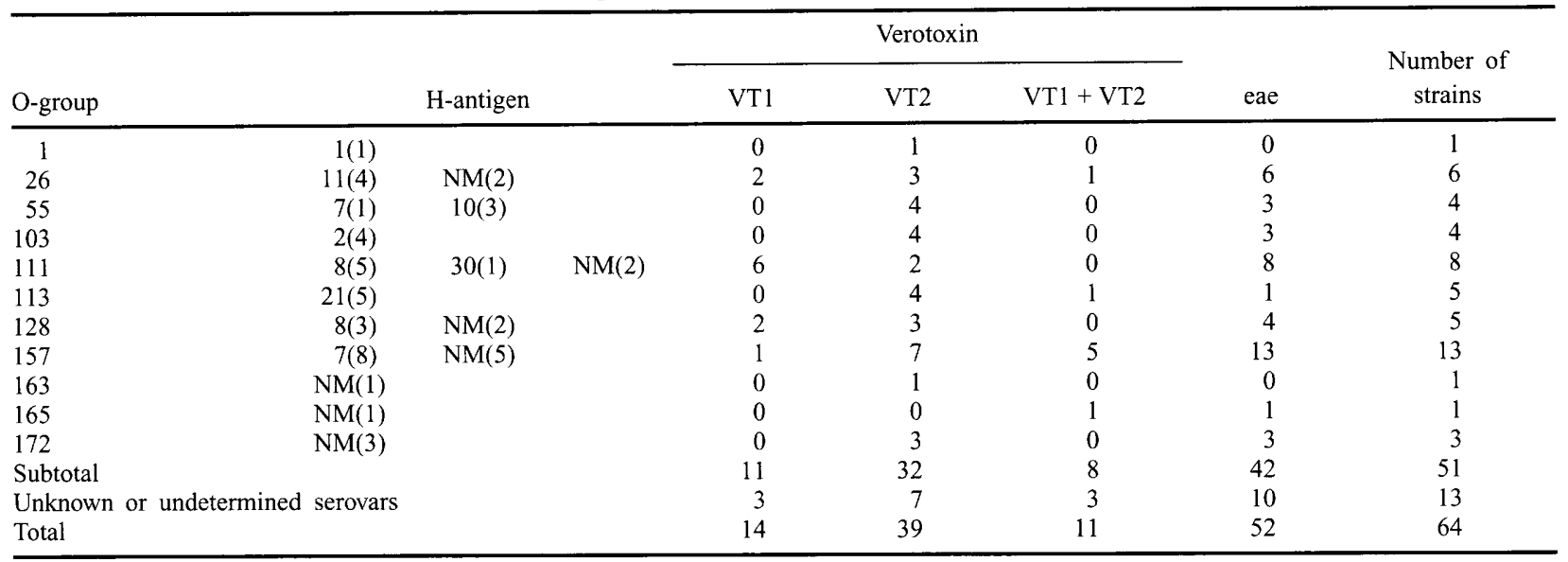

Figures in parentheses indicate the number of strains.

Table 4. Serovars of 745 strains of enteropathogenic E. coli

\begin{tabular}{|c|c|c|c|c|c|c|}
\hline \multirow{2}{*}{$\frac{\text { O-group }}{1}$} & \multicolumn{4}{|c|}{$\mathrm{H}$-antigen } & & \multirow{2}{*}{$\frac{\text { Number of strains }}{6}$} \\
\hline & $7(6)$ & & & & & \\
\hline 18 & $14(3)$ & $\mathrm{NM}(12)$ & & & & 15 \\
\hline 26 & $2(2)$ & $8(3)$ & $12(1)$ & $21(3)$ & $\mathrm{NM}(10)$ & 19 \\
\hline 44 & $18(6)$ & $28(2)$ & $33(2)$ & $\mathrm{NM}(7)$ & & 17 \\
\hline 55 & $5(3)$ & $6(12)$ & $33(4)$ & $34(4)$ & $\mathrm{NM}(36)$ & 59 \\
\hline 63 & $6(5)$ & $\mathrm{NM}(4)$ & & & & 9 \\
\hline 86 & $21(2)$ & $27(24)$ & $34(7)$ & $47(2)$ & $\mathrm{NM}(2)$ & 37 \\
\hline 103 & $19(1)$ & $\mathrm{NM}(13)$ & & & & 14 \\
\hline 111 & $2(2)$ & $5(1)$ & $12(7)$ & $21(8)$ & $\mathrm{NM}(28)$ & 46 \\
\hline 114 & $6(3)$ & $10(3)$ & $32(7)$ & NM(13) & & 26 \\
\hline 119 & $6(65)$ & $21(3)$ & $\mathrm{NM}(18)$ & & & 86 \\
\hline 125 & $19(3)$ & $21(13)$ & $\mathrm{NM}(8)$ & & & 24 \\
\hline 126 & $21(8)$ & $27(3)$ & NM(4) & & & 15 \\
\hline 127 & $10(2)$ & $21(4)$ & $\mathrm{NM}(18)$ & & & 24 \\
\hline 128 & $2(4)$ & $41(5)$ & $\mathrm{NM}(8)$ & & & 17 \\
\hline 142 & $6(25)$ & $33(11)$ & NM(19) & & & 55 \\
\hline 146 & $1(2)$ & $\mathrm{NM}(6)$ & & & & 8 \\
\hline 151 & $10(6)$ & $\mathrm{NM}(2)$ & & & & 8 \\
\hline 153 & $11(2)$ & NM(15) & & & & 17 \\
\hline 157 & $39(3)$ & $\operatorname{NM}(2)$ & & & & 5 \\
\hline 158 & $23(3)$ & $42(1)$ & & & & 4 \\
\hline 159 & $19(5)$ & $38(6)$ & $\mathrm{NM}(9)$ & & & 20 \\
\hline 160 & $7(1)$ & $33(4)$ & $48(2)$ & $\mathrm{NM}(9)$ & & 16 \\
\hline 162 & $\mathrm{NM}(5)$ & & & & & 5 \\
\hline 163 & $6(1)$ & $45(5)$ & $\mathrm{NM}(3)$ & & & 9 \\
\hline 165 & $7(5)$ & $\mathrm{NM}(15)$ & & & & 20 \\
\hline 166 & $4(6)$ & $6(2)$ & $\mathrm{NM}(10)$ & & & 18 \\
\hline 167 & $9(5)$ & $33(3)$ & $45(3)$ & $\mathrm{NM}(21)$ & & 32 \\
\hline 168 & $10(1)$ & NM(5) & & & & 6 \\
\hline 169 & $34(1)$ & $45(1)$ & $\mathrm{NM}(1)$ & & & 3 \\
\hline 171 & $\mathrm{NM}(4)$ & & & & & 4 \\
\hline OX2 & $9(2)$ & & & & & 2 \\
\hline OX4 & $8(4)$ & & & & & 4 \\
\hline OX13 & $8(4)$ & & & & & 4 \\
\hline Subtotal & & & & & & 654 \\
\hline Unknown & d serovars & & & & & 91 \\
\hline Total & & & & & & 745 \\
\hline
\end{tabular}

Figures in parentheses indicate the number of strains.

$\mathrm{OX} 2$, OX 4 and $\mathrm{OX} 13$ are $\mathrm{O}$-groups designated by Ewing.

NM, non-motile strain.

cause diarrhoea. However, the aetiological and epidemiological significance of DAEC remains controversial [16-21]. Similarly, the EAE gene occurs not only in EPEC, but also in VTEC strains. VTEC strains in which the gene coding for verotoxin production has been lost may thus be misidentified as EPEC strains.
Many of the serovars listed in the Tables, particularly those that occurred frequently, resemble those reported by other investigators [3, 12, 22-36]. For example, the principal serogroups of strains isolated from human diarrhoeal diseases by Ørskov and Ørskov [22] were found in this collection, although some differences of serovars were observed. A high proportion of ETEC 
isolates from Southeast Asia and the Middle East belong to a limited number of serogroups [23, 24, 29]. Similar results of serogroup distribution among ETEC isolates from Spain were reported $[31,32]$. In his review of adhesion and virulence of EPEC, Law [37] described EPEC serogroups and serovars traditionally associated with infantile diarrhoea. Most of these serogroups and serovars were also predominant in our EPEC collection. Scotland et al. [34] and Echeverria et al. [25] reported serogroups of EPEC found recently in diarrhoeal cases in Britain and Thailand, respectively. All of these serogroups were present in the EPEC strains in our collection. Although there is some variation, these findings suggest that the serovars of $E$. coli that cause diarrhoea may be more or less the same throughout the world. As has already been reported by others $[22,34,38,39]$, the occurrence of distinct categories of pathogenicity within a single Ogroup was observed frequently in this study. Of the 59 O-groups listed here, 24 occurred in more than one pathogenic category, although the combination of $\mathrm{O}$ and $\mathrm{H}$-antigens differed with the category. In this respect, five strains of O-serogroup 157 in the EPEC category are of interest as Schmidt et al. [40] and Scotland et al. [41] also reported non-toxigenic O157 strains. These non-toxigenic strains of O157 not only possessed $\mathrm{H}$-antigens other than $\mathrm{H} 7$ but also fermented sorbitol and produced $\beta$-glucuronidase, unlike VTEC 0157 strains. These findings suggest that phenotypic characterisation, including $\mathrm{H}$-antigen determination, may be important for understanding the relationships among the different pathogenic categories.

E. coli remains an important cause of infantile diarrhoea in developing countries. In industrial countries, although outbreaks caused by such $E$. coli occur occasionally, they constitute an important finding in travellers returning from warmer countries with diarrhoea. However, diarrhoeal disease caused by infection with ETEC and EPEC strains in adults and children is self-limiting. The full identification of strains of $E$. coli that cause diarrhoea includes serotyping based on both $\mathrm{O}$ - and $\mathrm{H}$-antigens as well as determination of virulence factors by various methods such as tissue cell culture assays and hybridisation with gene probes or PCR. These procedures are complex and time-consuming and, for this reason, are generally restricted to reference laboratories even in developed countries. However, EIEC strains produce dysentery-like symptoms and there is often person-to-person transmission of infection. In the absence of antisera for the EIEC serovars, antisera for Shigella may be used for presumptive identification because the O-antigens of EIEC serovars are closely related to those of Shigella serovars. Furthermore, H-antigen determination is not necessary for EIEC strains as most of them are non-motile. On the other hand, outbreaks of haemorrhagic colitis due to VTEC infection are a serious problem in industrial countries. Although various serovars are included in the VTEC category most outbreaks of haemorrhagic colitis are caused by O-group 157. In view of its importance, a selective isolation agar was developed for VTEC O157 strains [42] but as it does not detect all VTEC serovars, further identification of isolates from cases of haemorrhagic colitis may be necessary. Thus, the identification of EIEC and VTEC O157 strains can be achieved readily in routine laboratories with a small number of diagnostic antisera and only a few biochemical tests.

We thank Dr P. Echeverria, US Medical Institute of Research, Bangkok, for providing plasmids encoding virulence genes of $E$. coli.

\section{References}

1. Sakazaki R, Tamura K, Saito M. Enteropathogenic Escherichia coli associated with diarrhoea in children and adults. Jpn $J$ Med Sci Biol 1967; 20: 387-399.

2. Sakazaki R, Tamura K, Nakamura A. Further studies on enteropathogenic Escherichia coli associated with diarrhoeal diseases in children and adults. Jpn J Med Sci Biol 1974; 27: $7-18$.

3. Ewing WH. Edwards and Ewing's Identification of Enterobacteriaceae, 4th edn. New York, Elsevier. 1986.

4. Echeverria R, Seriwatana J, Sethabutr O, Chatkaemorakot A. Detection of diarrhoeagenic Escherichia coli using nucleotide probes. In: Macario ATL, Conway de Macario E (eds) Microbial gene. Orlando, Academic Press. 1990: 95-141.

5. Jerse $\mathrm{AE}, \mathrm{Yu} \mathrm{J}$, Tall $\mathrm{BD}$, Kaper JB. A genetic locus of enteropathogenic Escherichia coli necessary for the production of attaching and effacing lesions on tissue culture cells. Proc Natl Acad Sci USA 1990; 87: 7839-7843.

6. Gicquelais KG, Baldini MM, Martinez J et al. Practical and economical method for using biotinylated DNA probes with bacterial colony blots to identify diarrhea-causing Escherichia coli. J Clin Microbiol 1990; 28 2485-2490.

7. Dallas WS, Falkow S. The molecular nature of heat-labile enterotoxin (LT) of Escherichia coli. Nature 1979; 277: 406407.

8. Sommerfelt H, Kalland KG, Raj P, Moseley SL, Bhan MK, Bjorvatn B. Cloned polynucleotide and synthetic oligonucleotide probes used in colony hybridization are equally efficient in the identification of enterotoxigenic Escherichia coli. J Clin Microbiol 1988; 26: 2275-2278.

9. Boileau CR, d'Hauteville HM, Sansonetti PJ. DNA hybridization technique to detect Shigella species and enteroinvasive Escherichia coli. J Clin Microbiol 1984: 20 959-961.

10. Newland JW, Neill RJ. DNA probes for Shiga-like toxins I and II toxin-converting bacteriophages. J Clin Microbiol 1988; 26: 1292-1297.

11. Nataro JP, Scaletsky ICA, Kaper JB, Levine MM, Trabulsi LR Plasmid-mediated factors conferring diffuse and localized adherence of enteropathogenic Escherichia coli. Infect Immun 1985; 48: 378-383.

12. Schmidt H, Knop C, Franke S, Aleksic S, Heesemann J, Karch H. Development of PCR for screening of enteroaggregative Escherichia coli. J Clin Microbiol 1995; 33: 701-705.

13. Bhan MK, Raj P, Levine MM et al. Enteroaggregative Escherichia coli associated with persistent diarrhoea in a cohort of rural children in India. J Infect Dis 1989; 159: 10611064.

14. Cravioto A, Tello A, Navarro A et al. Association of Escherichia coli HEp-2 adherence patterns with type and duration of diarrhoea. Lancet 1991; 337: 262-264.

15. Scotland SM, Smith HR, Said B, Willshaw GA, Cheasty T, Rowe B. Identification of enteropathogenic Escherichia coli isolated in Britain as enteroaggregative or as members of a subclass of attaching-and-effacing $E$. coli not hybridising with the EPEC adherence-factor probe. $J$ Med Microbiol 1991; 35: $278-283$

16. Giron JA, Jones T, Millan-Velasco F et al. Diffuse-adhering Escherichia coli (DAEC) as a putative cause of diarrhea in 
Mayan children in Mexico. J Infect Dis 1991; 163: 507-513.

17. Gomes TAT, Blake PA, Trabulsi LR. Prevalence of Escherichia coli strains with localized, diffuse, and aggregative adherence to HeLa cells in infants with diarrhea and matched controls. $J$ Clin Microbiol 1989; 27: 266 269.

18. Tacket CO, Moseley SL, Kay B, Losonsky G, Levine MM Challenge studies in volunteers using Escherichia coli strains with diffuse adherence to HEp-2 cells. J Infect Dis 1990; 162 $550-552$

19. Ghosh AR, Nair GB, Naik TN, Mousumi Paul, Pal SC, Sen D. Entero-adherent Escherichia coli is an important diarrhoeagenic agent in infants aged below 6 months in Calcutta, India $J$ Med Microbiol 1992; 36: 264-268.

20. Brook MG, Smith HR, Bannister BA et al. Prospective study of verocytotoxin-producing, enteroaggregative and diffusely adherent Escherichia coli in different diarrhoeal states. Epidemiol Infect 1994; 112: 63-67.

21. Nataro JP, Kaper JB, Robins-Browne R, Prado V, Vial P, Levine MM. Patterns of adherence of diarrheagenic Escherichia coli to HEp-2 cells. Pediatr Infect Dis 1987; 6: 829-831.

22. Ørskov F, Ørskov 1. Escherichia coli serotyping and disease in man and animals. Can J Microbiol 1992; 38: 699-704.

23. DeBoy JM, II, Wachsmuth IK, Davis BR. Serotypes of enterotoxigenic Escherichia coli isolated in the United States. Infect Immun 1980; 29: 361-368.

24. Echeverria P, Ørskov F, Ørskov I, Plianbangchang D. Serotypes of enterotoxigenic Escherichia coli in Thailand and the Philippines. Infect Immun 1982; 36: 851-856.

25. Echeverria P, Taylor DN, Betthelheim KA et al. HeLa cell adherent Escherichia coli in children under 1 year of age in Thailand. J Clin Microbiol 1987; 25: 1472-1475.

26. Echeverria P, Taylor DN, Seriwatana J, Brown JE, Lexomboom $\mathrm{U}$. Examination of colonies and stool blots for detection of enteropathogens by DNA hybridization with eight DNA probes. J Clin Microbiol 1989; 27: 331-334.

27. Echeverria P, Ørskov F, Ørskov I et al. Attaching and effacing enteropathogenic Escherichia coli as a cause of infantile diarrhea in Bangkok. $J$ Infect Dis 1991; 164: 550-554.

28. Rowe B, Gross R, Takeda Y. Serotyping and enterotoxigenic Escherichia coli isolated from diarrhoeal travellers from various countries. FEMS Microbiol Lett 1983; 20: 187-189.

29. Bopp CA, Greene KD, Downes EP, Sowers EG, Wells JG, Wachsmuth IK. Unusual verotoxin-producing Escherichia coli associated with hemorrhagic colitis. J Clin Microbiol 1987; 25 1486-1489.

30. Betthelheim KA, Brown JW, Lolokha S, Echeverria P. Serotypes of Escherichia coli that hybridize with DNA probes for genes encoding Shiga-like toxin I, Shiga-like toxin II, and serogroup 0157 enterohemorrhagic $E$. coli fimbriae from adults with diarrhea in Thiland. J Clin Microbiol 1990; 28: 295-298.

31. Blanco J, Blanco M, Garabal JI, Gonzalez EA. Enterotoxins, colonization factors and serotypes of enterotoxigenic Escherichia coli from human and animals. Microbiologia 1991; 7: $57-73$.

32. Blanco J, González EA, Blanco $\mathrm{M}$ et al. Enterotoxigenic Escherichia coli associated with infant diarrhoea in Galicia, north-western Spain. J Med Microbiol 1991; 35: 162-167.

33. Knutton S, Phillips AD, Smith HR et al. Screening of enteropathogenic Escherichia coli in infants with diarrhea by the fluorescent-actin staining test. Infect Immun 1991; 59: 365371.

34. Scotland SM, Willshaw GA, Smith HR, Said B, Stokes N, Rowe B. Virulence properties of Escherichia coli strains belonging to serogroups $\mathrm{O} 25, \mathrm{O} 55, \mathrm{O} 111$ and $\mathrm{O} 128$ isolated in the United Kingdom in 1991 from patients with diarrhoea. Epidemiol Infect 1993; 111: 429-438.

35. Bockemuhl J, Aleksic S, Karch H. Serological and biochemical properties of Shiga-like toxin (verocytotoxin)-producing strains of Escherichia coli, other than O-group 157, from patients in Germany. Int J Med Microbiol Virol Parasitol Infect Dis 1992; 276: $189-195$

36. Wolf MK, Taylor DN, Boedeker EC et al. Characterization of enterotoxigenic Escherichia coli isolated from U.S. troops deployed to the Middle East. J Clin Microbiol 1993; 31: 851856.

37. Law D. Adhesion and its role in the virulence of enteropathogenic Escherichia coli. Clin Microbiol Rev 1994; 7: 152-173.

38. Campos LC, Whittman TS, Gomez TAT, Andrade JRC, Trabulsi LR. Escherichia coli serogroup O111 includes several clones of diarrheagenic strains with different virulence properties. Infect Immun 1994; 62: 3282-3288.

39. Yam WC, Robins-Browne RM, Lung ML. Genetic relationships and virulence factors among classical enteropathogenic Escherichia coli serogroup 0126 strains. $J$ Med Microbiol 1994; 40: 229-235.

40. Schmidt H, Rüssmann $H$, Karch $H$. Virulence determinants in nontoxinogenic Escherichia coli 0157 strains that cause infantile diarrhea. Infect Immun 1993; 61: 4894-4898.

41. Scotland SM, Willshaw GA, Cheasty T, Rowe B. Strains of Escherichia coli $\mathrm{O} 157: \mathrm{H} 8$ from human diarrhoea belong to attaching and effacing class of E. coli. J Clin Pathol 1992; 45: 1075-1078.

42. Zadik PM, Chapman PA, Siddons CA. Use of tellurite for the selection of verocytotoxigenic Escherichia coli O157. J Med Microbiol 1993; 39: 155-158. 